\title{
PENGARUH KOMPETENSI DAN SEMANGAT KERJA TERHADAP PRESTASI KERJA GURU
}

\author{
Oleh : Didit Darmawan
}

\begin{abstract}
This research aims to study the influence of competence and morale to work performance. The analysis method applied in study the influence of competence and morale to work performance are descriptive and quantitative analysis by multiple linear regression model. The statistic test was done by t-test and F-test, where firstly did the classic assumption test before did the statistic test. $t$-test is used to know the influence of independent variable to the dependent variable partially, while the F-test is used to know the influence of independent variable to the dependent variable simultantly. Variables used in this research are competence and morale as independent variables, and work performance as dependent variable.

The result of this research show that, partially competence and morale partially influence toward work performance. Simultaneously competence and morale influence toward work performance using the regression equation $Y=1.744+0.504 X 1+0.621 X 2 . R$ Square that shows value 0,164 indicates that $16,4 \% Y$ can be determined by the independent variable in this research, mean while, the remainder $83,6 \%$ detemined by other factors which not include in this research.
\end{abstract}

Keywords : competence, morale, work performance

\begin{abstract}
ABSTRAK
Penelitian ini mengkaji pengaruh kompetensi dan semangat kerja terhadap prestasi kerja. Analisis yang digunakan untuk mengkaji pengaruh kompetensi dan semangat kerja terhadap prestasi kerja adalah dengan menggunakan analisis deskriptif dan analisis kuantitatif melalui teknik analisis regresi linier berganda. Uji statistik yang digunakan adalah uji $\mathrm{t}$ dan uji $\mathrm{F}$ dimana terlebih dahulu dianalisis melalui uji asumsi klasik. Uji t digunakan untuk menganalisis pengaruh secara parsial variabel bebas terhadap variabel terikat, sedangkan uji $\mathrm{F}$ digunakan menganalisis pengaruh secara simultan. Dua variabel bebas adalah kompetensi dan semangat kerja. Sedangkan variabel terikat adalah prestasi kerja.

Hasil penelitian menunjukkan bahwa secara parsial kompetensi dan semangat kerja berpengaruh signifikan terhadap prestasi kerja. Secara simultan, kompetensi dan semangat kerja berpengaruh terhadap prestasi kerja dengan menggunakan rumus regresi $\mathrm{Y}=1.744+0.504 \mathrm{X} 1+0.621 \mathrm{X} 2$. Nilai Rsquare sebesar 0.164 yang berarti bahwa $16.4 \%$ variabel terikat terbentuk dari kontribusi variabel bebas, sedangkan sisanya $83.6 \%$ dibentuk oleh faktor-faktor lainnya.
\end{abstract}

Kata - kata kunci : kompetesi, semangat, prestasi kerja 


\section{PENDAHULUAN}

\section{Latar Belakang Masalah}

Peranan sumber daya manusia semakin penting artinya untuk menentukan kelangsungan hidup suatu organisasi, karena organisasi tidak dapat berkembang dengan baik dan bertahan hidup lama meski didukung oleh sumber daya fisikal yang lengkap, bila tanpa sumber daya manusia yang bermoral baik, dinamis dan bersatu. Dengan demikian, faktor manusia menjadi faktor yang sangat penting untuk menentukan keberhasilan organisasi mencapai tujuannya.

Sumber daya manusia yang ada di organisasi harus selalu dikembangkan secara berkesinambungan untuk meningkatkan kompetensi agar sesuai dengan tuntutan lingkungan kerja. Masalah prestasi kerja adalah merupakan salah satu bagian penting keberhasilan mencapai tujuan organisasi. Untuk meningkatkan prestasi kerja tidak hanya tergantung pada kecanggihan teknologi dan suasana kerja yang kondusif, namun unsur yang terpenting adalah kualitas sumber daya manusia yang menjalankan aktivitas tersebut. Ini berarti faktor sumber daya manusia mempunyai andil yang cukup besar dan merupakan modal terpenting serta sangat berpengaruh besar terhadap perkembangan dan keberhasilan organisasi. Pekerja merupakan unsur pelaksana dari semua program dan kebijakan organisasi untuk menjalankan pekerjaannya mereka selalu dilandasi oleh keinginan untuk mencapai tujuan tertentu.

Prestasi kerja yang tinggi dari guru memberi dorongan pada pengembangan kompetensi kerja sehingga pada setiap diri guru memiliki peranan penting untuk memberikan kontribusi pada kinerja guru. Prestasi kerja yang tinggi dari guru ditandai dengan berkembangnya kompetensi kerja. Kompetensi kerja adalah suatu kapasitas individu secara menyeluruh untuk mengerjakan berbagai pekerjaannya. Kompetensi diperlukan seseorang untuk menyelesaikan pekerjaan. Hal ini berarti bahwa untuk menyelesaikan suatu pekerjaan selalu masih tersedia suatu tingkat kemampuan yang belum dipergunakan oleh seseorang. Kompetensi menunjukkan potensi dan kemampuan orang untuk melaksanakan tugas atau pekerjaannya. Kompetensi berhubungan erat dengan kemauan, pengetahuan, kemampuan fisik dan mental yang dimiliki oleh seseorang untuk melaksanakan pekerjaannya. Setiap jenis pekerjaan menuntut pengetahuan, keterampilan dan sikap tertentu agar dapat melaksanakan pekerjaan tersebut dengan baik. Untuk mencapai prestasi setinggi-tingginya seseorang harus mengeluarkan seluruh kemampuannya secara optimal.

Para pimpinan harus secara bijak memperhatikan kebutuhan para guru secara tepat. Semangat kerja guru juga dapat menurun apabila pihak atasan tidak memperhatikan kepentingan para bawahan. Hal ini akan menurunkan semangat kerja para guru. Indikator dari turunnya semangat kerja antara lain rendahnya produktivitas, tingkat absensi guru tinggi, gaji rendah, dan lain-lain. Dengan demikian pastilah akan mempengaruhi semangat kerja guru di suatu organisasi. Kebutuhan terpenuhi dalam waktu relatif lama tidak dapat menjadi motivator yang aktif selama ini dilakukan. Kebutuhan yang tidak terpenuhi menyebabkan orang dapat menunjukkan sikap menentang, dan bahkan frustasi, dan jika hal ini terjadi pada guru dapat menyebabkan kurangnya gairah kerja untuk melakukan tugasnya. Orang bekerja keras bila mereka merasa bahwa kerja kerasnya akan mendapat penghargaan yang bernilai bagi organisasinya. Manusia memiliki semangat kerja yang bersifat positif maupun negatif serta motivasi berupa material atau sosial/kejiwaan. Melalui semangat kerja akan diharapan hasilnya lebih baik karena disertai kegairahan dan keikhlasan untuk bekerja. Pada akhirnya dengan kompetensi dan semangat yang optimal diharapkan akan membentuk prestasi kerja guru yang optimal pula. 
Prestasi kerja adalah hasil dari kemampuan seseorang untuk usaha mencapai tujuan kerja yang lebih baik dan lebih berkembang ke arah tercapainya tujuan organisasi. Prestasi kerja sangat dipengaruhi oleh adanya kompentesi dan semangat kerja guru di suatu lembaga. Hal inilah yang akan membentuk sistem organisasi berjalan dengan baik. Bila sistem organisasi berjalan baik diharapkan memudahkan untuk menegakkan disiplin kerja sehingga pekerjaan dapat terlaksana dengan baik maka tujuan organisasi dapat tercapai sesuai harapan. Dengan demikian penelitian ini bermaksud untuk mengambil topik yang berjudul pengaruh kompetensi dan semangat terhadap prestasi kerja guru.

\section{Rumusan Masalah}

Berdasarkan uraian pada latar belakang masalah sebelumnya, maka rumusan masalah di penelitian ini adalah sebagai berikut:

1. Apakah kompetensi dan semangat berpengaruh parsial secara signifikan terhadap prestasi kerja guru?

2. Apakah kompetensi dan semangat berpengaruh simultan secara signifikan terhadap prestasi kerja guru?

3. Di antara kompetensi dan semangat, variabel mana yang berpengaruh dominan terhadap prestasi kerja guru?

\section{Tujuan Penelitian}

Berdasarkan rumusan masalah yang telah ditetapkan sebelumnya, maka tujuan penelitian ini adalah sebagai berikut:

1. Untuk menganalisis dan mengetahui pengaruh kompetensi dan semangat secara parsial terhadap prestasi kerja guru

2. Untuk menganalisis dan mengetahui pengaruh kompetensi dan semangat secara simultan terhadap prestasi kerja guru

3. Untuk menganalisis dan mengetahui variabel yang berpengaruh dominan terhadap prestasi kerja guru

\section{KAJIAN TEORITIS}

Kompetensi menurut Spencer (1993) dalam Pfeffer, dkk (2003:109) yaitu karakteristik yang mendasari seseorang dan berkaitan dengan efektifitas kinerja individu dalam pekerjaanya (an underlying characteristi's of an individual which is causally related to criterion referenced effective and or superior performance in a job or situation). Berdasarkan definisi tersebut kata An underlying characteristi's mengandung makna kompetensi adalah bagian kepribadian yang mendalam dan melekat kepada seseorang serta perilaku yang dapat diprediksi pada berbagai keadaan dan tugas pekerjaan. Sedangkan kata causally related berarti kompetensi adalah sesuatu yang menyebabkan atau memprediksi perilaku dan kinerja. Dan kata criterion referenced mengandung makna bahwa kompetensi sebenarnya memprediksi siapa yang berkinerja baik dan kurang baik, diukur dari kriteria atau standar yang digunakan. 
Spencer and Spencer (1993) dalam Pfeffer, dkk (2003:113) menurut kriteria yang digunakan memprediksi kinerja suatu pekerjaan bahwa kompetensi dibagi atas 2 (dua) kategori yaitu :

a. Threshold Competencies adalah karateristik utama (biasanya pengetahuan atau keahlian dasar seperti kemampuan untuk membaca) yang harus dimiliki seseorang agar dapat melaksanakan pekerjaannya.

b. Differentiating Competencies adalah faktor-faktor yang membedakan individu yang berkinerja tinggi dan rendah. Misalnya, seseorang yang memiliki orientasi motivasi (konsep diri), biasanya yang diperhatikan pada penetapan tujuan yang melebihi apa yang ditetapkan organisasi

Sastrohadiwiryo (2002:35) menyatakan bahwa semangat kerja adalah keadaan psikologis seseorang yang menimbulkan kesenangan yang mendorong seseorang untuk bekerja dengan giat dan konsekuen untuk mencapai tujuan yang ditetapkan organisasi.

Arti prestasi kerja adalah hasil kerja yang dapat dicapai oleh seseorang atau sekelompok orang di suatu organisasi, sesuai dengan wewenang dan tanggung jawab masing-masing, dalam rangka upaya mencapai tujuan organisasi bersangkutan secara legal, tidak melanggar hukum dan sesuai dengan moral ataupun etika. Menurut Suyadi (1999:3), prestasi kerja adalah hasil kerja yang dapat dicapai oleh seseorang atau sekelompok orang di suatu oraganisasi sesuai dengan wewenang dan tanggung jawab dalam rangka mencapai tujuan organisasi.

\section{Kerangka Konseptual}

Penelitian ini akan mengkaji hubungan-hubungan tersebut seperti yang dirumuskan pada kerangka konseptual penelitian berikut ini.

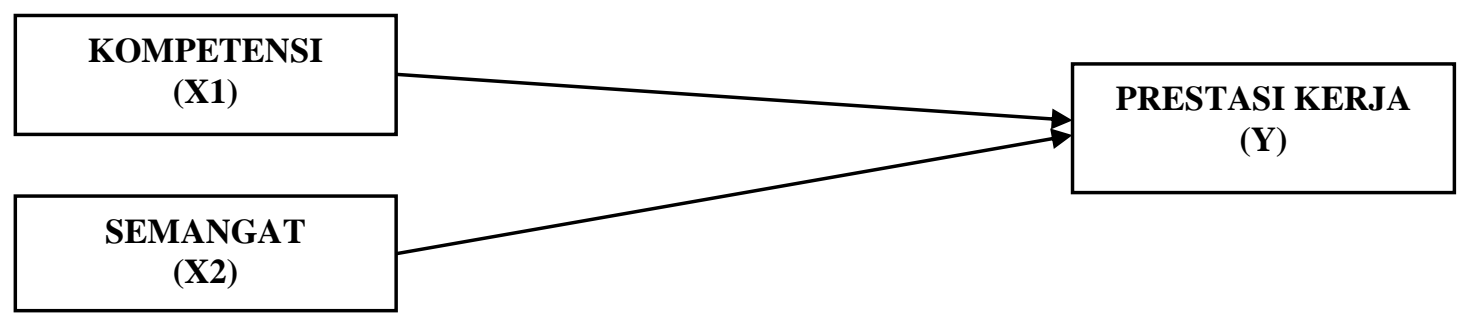

Gambar 1

Kerangka Konseptual

\section{Hipotesis Penelitian}

Hipotesis di penelitian ini ditetapkan sebagai berikut:

1. Kompetensi dan semangat berpengaruh parsial secara signifikan terhadap prestasi kerja guru

2. Kompetensi dan semangat berpengaruh simultan secara signifikan terhadap prestasi kerja guru

3. Semangat kerja berpengaruh dominan secara nyata terhadap prestasi kerja guru. 


\section{METODE PENELITIAN}

Berdasarkan pada tujuan yang ingin dicapai di penelitian ini yaitu menjelaskan pengaruh variabel yang lainnya, maka penelitian ini termasuk penelitian penjelasan atau explanatory research. Populasi pada penelitian ini adalah guru di Kota Sidoarjo. Pada penelitian ini sampel diambil dari seluruh anggota populasi karena jumlah populasi yang banyak sehingga pengambilan sampel dilakukan dengan cara incedential sampling, yaitu dipilih dijadikan sampel berdasarkan cuplikan suatu kejadian saat berkumpulnya anggota populasi yang menjadi subjek penelitian. Jumlah responden ditetapkan sebanyak 77 guru. Berikut adalah identifikasi variabel penelitian.

\section{Kompetensi (X1)}

Kombinasi antara kemampuan potensi dan pengetahuan serta keterampilan. Indikatornya adalah:

a. Kemampuan untuk mengambil keputusan

b. Kemampuan menyelesaikan masalah

c. Kemampuan analisis masalah

d. Kemampuan teknikal

e. Kemampuan konseptual

f. Kemampuan untuk menyesuaikan diri

\section{Semangat (X2)}

Suatu dorongan atau penggerak yang terdapat dalam diri manusia, yang dapat menimbulkan, mengarahkan, mengorganisasikan tingkah lakunya. Indikator-indikator yang dipergunakan untuk mengukur semangat kerja adalah:

a. Perhatian pimpinan terhadap guru tentang pendapatnya

b. Menghargai ide dan cita-citanya

c. Pujian pimpinan terhadap prestasi guru

d. Pemenuhan kebutuhan guru.

e. Kegairahan tertunjuk secara afektif

f. Antusiasme bekerja

\section{Prestasi Kerja (Y)}

Prestasi kerja adalah suatu hasil kerja yang dicapai seseorang untuk melaksanakan tugas-tugas yang dibebankan kepadanya yang didasarkan atas kecakapan, pengalaman dan kesungguhan serta waktu. Prestasi Kerja (Y) memiliki beberapa indikator seperti sebagai berikut:

a. Memahami tugas dan tanggung jawab

b. Memahami keputusan dan tindakan yang diambil

c. Hubungan kerja

d. Menyelesaikan tugas kerja secara tepat waktu

e. Memelihara sikap kerja

f. Profesionalisme 
Pengukuran data di penelitian ini adalah daftar pertanyaan yang disusun berdasarkan indikator variabel. Daftar pertanyaan yang disusun mengikuti model skala Likert. Uji validitas digunakan sejauh mana alat ukur benar-benar mampu mengukur variabel-variabel yang akan digunakan di penelitian yang bersangkutan. Setelah alat dinyatakan valid kemudian dicari reliabilitasnya (ketepatan atau keakuratannya). Ketepatan suatu instrumen ditujukan oleh bagaimana kemampuan instrumen tersebut dapat diukur dengan tepat. Pada tahap analisis data akan digunakan beberapa tahap pengelolahan data yang dibantu dengan program SPSS. Untuk memperoleh data yang dapat dipercaya diperlukan alat pengumpulan data yang valid dan reliabel. Uji asumsi klasik juga digunakan untuk mengetahui pengesahan penggunaan model regresi linear berganda. Model regresi linier berganda akan lebih tepat digunakan dan menghasilkan perhitungan yang lebih akurat bila beberapa asumsi klasik seperti heteroskedastisitas, normalitas, autokorelasi. Analisis regresi linier berganda digunakan untuk mengetahui besarnya intensitas/pengaruh masing-masing variabel bebas terhadap variabel terikat. Persamaan Regresi Linier Berganda adalah sebagai berikut : $\mathrm{Y}=\mathrm{a}+\beta 1 \mathrm{X} 1+\beta 2 \mathrm{X} 2$, Di mana:

$$
\begin{array}{lll}
\mathrm{Y} & = & \text { Prestasi Kerja } \\
\mathrm{X} 1 & = & \text { Kompetensi } \\
\mathrm{X} 2 & = & \text { Semangat }
\end{array}
$$

$B 1=$ Koefisien regresi Kompetensi

B2 = Koefisien regresi Semangat

$\mathrm{a} \quad=\quad$ Konstanta

Uji F yaitu perhitungan untuk mengetahui pengaruh bersama-sama dari variabel bebas (kompetensi dan semangat kerja) terhadap variabel terikat (prestasi kerja). Uji t yaitu perhitungan untuk mengetahui pengaruh masing-masing variabel bebas (kompetensi dan semangat kerja) terhadap variabel terikat (prestasi kerja). Koefisien determinasi sebenarnya mengukur sejauh mana peranan variabel bebas terhadap variabel terikat.

\section{ANALISIS HASIL PENELITIAN DAN PEMBAHASAN}

\section{Uji Validitas dan Uji Reliabilitas}

Konsep dari validitas adalah sejauh mana tingkat ketelitian, ketepatan dan kecermatan fungsi skala ukur yang tepat sesuai tujuan penelitian. Ketepatan alat ukur berarti dapat memberikan gambaran mengenai perbedaan yang ada sekecil mungkin antara obyek satu dengan obyek lainnya. Bila instrumen alat ukur dapat menjalankan fungsinya dengan baik maka instrumen dapat memiliki tingkat validitas yang tinggi. Pada pengujian kompetensi kerja (X1) dihasilkan dan ditunjukkan seperti pada Tabel 1 berikut ini. 
Tabel 1

Uji Validitas Variabel

\begin{tabular}{|c|c|c|c|}
\hline No & Variabel & $\mathbf{R}$ & Validitas \\
\hline \hline 1 & $\mathrm{X} 1.1$ & 0,412 & Valid \\
\hline 2 & $\mathrm{X} 1.2$ & 0,462 & Valid \\
\hline 3 & $\mathrm{X} 1.3$ & 0,315 & Valid \\
\hline 4 & $\mathrm{X} 1.4$ & 0,308 & Valid \\
\hline \hline 5 & $\mathrm{X} 1.5$ & 0,312 & Valid \\
\hline 6 & $\mathrm{X} 1.6$ & 0,465 & Valid \\
\hline 7 & $\mathrm{X} 2.1$ & 0,517 & Valid \\
\hline 8 & $\mathrm{X} 2.2$ & 0,652 & Valid \\
\hline 9 & $\mathrm{X} 2.3$ & 0,437 & Valid \\
\hline \hline 10 & $\mathrm{X} 2.4$ & 0,525 & Valid \\
\hline 11 & $\mathrm{X} 2.5$ & 0,572 & Valid \\
\hline 12 & $\mathrm{X} 2.6$ & 0,437 & Valid \\
\hline \hline 13 & $\mathrm{Y} 1.1$ & 0,552 & Valid \\
\hline \hline 14 & $\mathrm{Y} 1.2$ & 0,532 & Valid \\
\hline \hline 15 & $\mathrm{Y} 1.3$ & 0,564 & Valid \\
\hline \hline 16 & $\mathrm{Y} 1.4$ & 0,437 & Valid \\
\hline 17 & $\mathrm{Y} 1.5$ & 0,453 & Valid \\
\hline 18 & $\mathrm{Y} 1.6$ & 0,526 & \\
\hline
\end{tabular}

Sumber hasil olahan SPSS

Pada penelitian ini ditetapkan batas setiap item pertanyaan dinyatakan valid bila nilai corrected item total correlation lebih besar dari nilai 0,3 . diketahui bahwa setiap item pernyataan dari berada di atas batas 0,3 . Dengan demikian tidak ada item pertanyaan yang digugurkan dari format asalnya. Kesimpulannya adalah setiap item pertanyaan pada kuesioner dinyatakan valid.

Reliabilitas adalah alat yang digunakan untuk mengetahui tingkat kehandalan dari alat ukur yang dipakai, semakin tinggi nilai reliabilitas maka alat ukur yang dipakai juga lebih baik (andal) untuk digunakan di penelitian selanjutnya atau tempat yang berbeda. Metode yang digunakan adalah dengan ketetapan nilai alpha diatas 0,6.

Tabel 2

Uji Reliabilitas

\begin{tabular}{|c|c|c|c|}
\hline No & Variabel & Alpha & Reliabilitas \\
\hline \hline 1 & $\mathrm{X} 1$ & 0,702 & Reliabel \\
\hline 2 & $\mathrm{X} 2$ & 0,615 & Reliabel \\
\hline 3 & $\mathrm{Y}$ & 0,603 & Reliabel \\
\hline
\end{tabular}

Sumber hasil olahan SPSS 
Hasil pengujian reliabilitas menunjukkan bahwa nilai kooefisien reliabilitas masing-masing variabel yang digunakan dalam variabel diatas lebih besar dari nilai 0,6. Dengan demikian hasil jawaban responden dapat diandalkan dengan kata lain bahwa apabila dilakukan penelitian yang sama dalam waktu berbeda maka responden akan memberikan jawaban yang sama.

\section{Uji Asumsi Klasik}

Uji Normalitas untuk mengukur suatu model regresi penelitian bahwa variabel-variabel bebas dan terikat mempunyai distribusi normal atau tidak. Model regresi yang baik bila data di penelitian yang mempunyai distribusi data normal atau mendekati normal. Salah satu cara untuk melihat normalitas adalah melihat normal probability plot berikut ini.

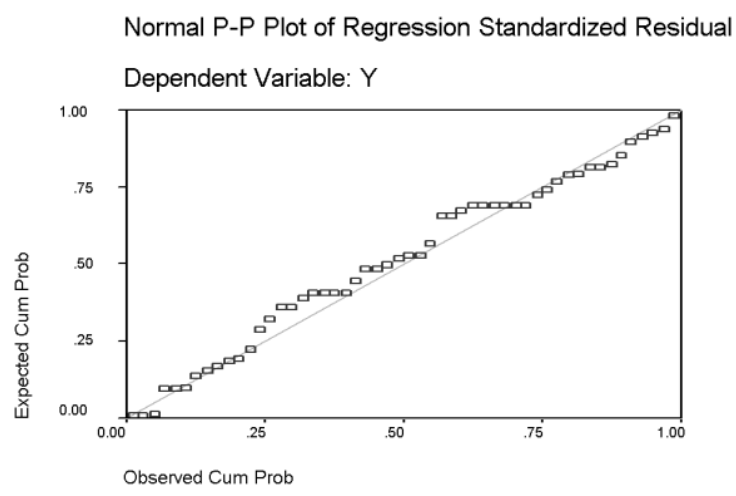

Gambar 2

Sebaran Data Normal

Sumber hasil olahan SPSS

Hasil pengolahan SPSS yang ditunjukkan gambar diatas dapat dikatakan bahwa grafik terlihat titik-titik yang menyebar disekitar diagonal atau garis normal, serta penyebarannya mengikuti arah garis diagonal. Maka model regresi pada penelitian ini layak dipakai karena memenuhi asumsi normalitas.

Autokorelasi dapat didefinisikan sebagai korelasi antara anggota serangkaian yang diurutkan menurut waktu (seperti dalam data deret waktu) atau ruang (sejumlah data). Untuk melihat ada tidaknya problem autokorelasi digunakan dengan metode statistik dari Durbin-Watson.

Tabel 3

Durbin-Watson

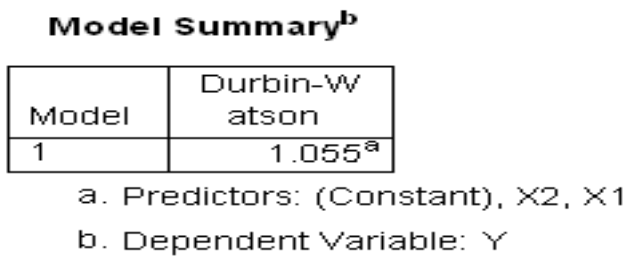

Sumber hasil olahan SPSS 
Hasil perhitungan SPSS yang dilakukan penulis diperoleh Durbin-Watson sebesar 1,055 seperti tertulis pada lampiran. Nilai tersebut berada pada 1,01 s/d 2,46 yang berarti model regresi pada penelitian in bebas dari autokorelasi.

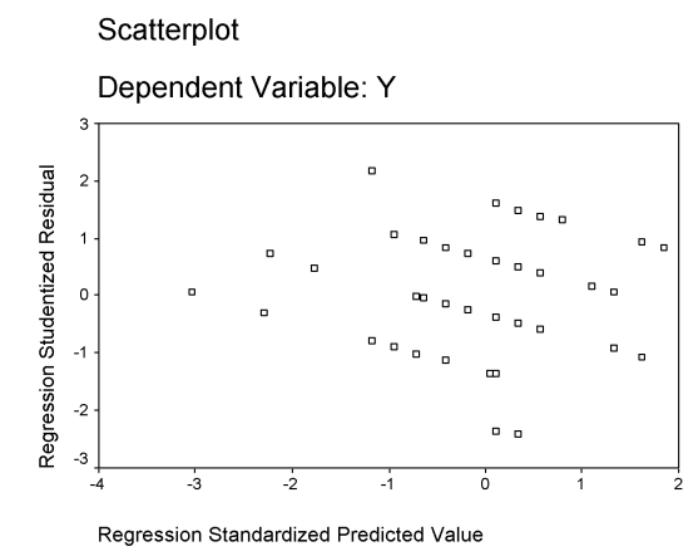

Gambar 3

Scatterplot Dependent Variable

Sumber hasil olahan SPSS

Uji heteroskedastisitas bertujuan menguji apakah dalam model regresi terjadi ketidaksamaan variance dari residual satu pengamatan ke pengamatan lain. Caranya adalah dengan cara mengamati scatterplot pada dependent variable. Gambar 3 menunjukkan bahwa titik-titik pada scatterplot tersebar dan berada pada masing-masing bagian di sumbu Y. Dengan demikian dapat disimpulkan bahwa tidak terjadi heteroskedastisitas.

\section{Analisis Regresi Berganda}

Koefisien korelasi mengukur tingkat keeratan hubungan antara faktor bebas yaitu variabel bebas yang terdiri dari variabel kompetensi kerja (X1) dan semangat kerja (X2) terhadap variabel terikat prestasi kerja guru. Hasil SPSS mengenai koefisien korelasi dan determinasi ditunjukkan oleh tabel berikut.

\section{Tabel 4}

Koefisien Determinasi

\begin{tabular}{|l|r|r|r|r|}
\hline Model & \multicolumn{1}{|c|}{$\mathrm{R}$} & R Square & $\begin{array}{l}\text { Adjusted } \\
\text { R Square }\end{array}$ & $\begin{array}{r}\text { Std. Error of } \\
\text { the Estimate }\end{array}$ \\
\hline 1 & $.405^{\mathrm{a}}$ & .164 & .130 & .20803 \\
\hline
\end{tabular}

a. Predictors: (Constant), $\times 2, \times 1$

Sumber hasil olahan SPSS

Berdasarkan hasil perhitungan SPSS yang disajikan pada tabel 4 dapat diketahui bahwa koefisien korelasi (R) adalah 0,405 atau mendekati 1 . Artinya hubungan antara variabel bebas yaitu variabel kompetensi kerja (X1) dan semangat kerja (X2) terhadap variabel terikat prestasi kerja guru adalah sangat erat (kuat searah). Dimana perubahan kenaikan yang terjadi pada variabel terikat yaitu prestasi kerja guru, begitu pula sebaliknya. Persentase variabel kompetensi kerja (X1) dan semangat kerja (X2) terhadap variabel terikat prestasi kerja guru ditunjukkan oleh 
koefisien determinasi simultan $\left(\mathrm{R}_{\text {squared }}\right)$ adalah sebesar 0,164 atau $16,4 \%$. Artinya naik turunnya variabel terikat yaitu prestasi kerja guru dipengaruhi variabel terikat kompetensi kerja (X1) dan semangat kerja (X2) sebesar 16,4\%. Sedangkan sisanya sebesar 83,6\% dipengaruhi variabel lain di luar penelitian ini.

Pengujian pengaruh parsial atau uji t digunakan untuk mengukur pengaruh tingkat signifikansi secara parsial antara variabel bebas yaitu kompetensi kerja (X1) dan semangat kerja (X2) terhadap variabel terikat prestasi kerja guru. Adapun hasil pengolahan SPSS diperoleh signifikansi pada nilai thitung sebagai berikut:

Tabel 5

Nilai tHitung dan Signifikansi

\begin{tabular}{|c|c|c|c|c|c|c|}
\hline \multirow{2}{*}{\multicolumn{2}{|c|}{ Model }} & \multicolumn{2}{|c|}{$\begin{array}{l}\text { Unstandardized } \\
\text { Coefficients }\end{array}$} & \multirow{2}{*}{$\begin{array}{l}\text { Standardized } \\
\text { Coefficients } \\
\text { Beta }\end{array}$} & \multirow[b]{2}{*}{$\mathrm{t}$} & \multirow[b]{2}{*}{ Sig. } \\
\hline & & $\mathrm{B}$ & Std. Error & & & \\
\hline \multirow[t]{3}{*}{1} & (Constant) & 1.744 & .749 & & 2.327 & .024 \\
\hline & $\times 1$ & .504 & .163 & .392 & 2.638 & .005 \\
\hline & $\times 2$ & 621 & .206 & 436 & 3.021 & .004 \\
\hline
\end{tabular}

a. Dependent Variable: $Y$

Sumber hasil olahan SPSS

Dari hasil perhitungan dengan uji t di atas maka dapat diinterprestasikan sebagai berikut :

1. Untuk variabel kompetensi kerja $\left(\mathrm{X}_{1}\right)$, nilai t hitung yang diperoleh adalah sebesar 2,638 dan signifikansinya adalah 0,005 . Nilai ini lebih kecil dari pada $\alpha=0,05$, sehingga Ho ditolak dan Ha diterima yang berarti bahwa variabel kompetensi kerja $\left(\mathrm{X}_{1}\right)$ secara parsial memiliki pengaruh signifikan terhadap variabel terikat yaitu prestasi kerja guru.

2. Untuk variabel semangat kerja $\left(\mathrm{X}_{2}\right)$, nilai t hitung yang diperoleh adalah sebesar 3,021 dan nilai signifikansinya adalah 0,004 . Nilai ini lebih kecil dari pada $\alpha=0,05$, sehingga Ho ditolak dan Ha diterima yang berarti bahwa variabel semangat kerja $\left(\mathrm{X}_{2}\right)$ secara parsial memiliki pengaruh signifikan terhadap variabel terikat yaitu prestasi kerja guru.

Pengujian simultan atau uji $\mathrm{F}$ digunakan untuk mengukur pengaruh tingkat signifikansi secara bersama antara variabel bebas yaitu kompetensi kerja (X1) dan semangat kerja (X2) terhadap variabel terikat prestasi kerja guru. Adapun hasil pengolahan SPSS diperoleh signifikansi pada nilai $\mathrm{F}$ hitung sebagai berikut :

Tabel 6

Nilai Uji F Dan Signifikansi

ANOVA

\begin{tabular}{|ll|r|r|r|r|r|}
\hline Model & \multicolumn{1}{|c|}{$\begin{array}{c}\text { Sum of } \\
\text { Squares }\end{array}$} & df & Mean Square & F & Sig. \\
\hline 1 & Regression & .417 & 2 & .209 & 4.819 & $.012^{\text {a }}$ \\
Residual & 2.121 & 75 & .043 & & \\
Total & 2.538 & 77 & & & \\
\hline
\end{tabular}

Sumber hasil olahan SPSS 
Sesuai dengan hasil perhitungan uji F yang dilakukan dengan bantuan program SPSS diperoleh nilai $F$ hitung sebesar 4,819. Nilai signifikansi yang diperoleh sebesar 0,012 nilai signifikansi ini lebih kecil dari nilai $\alpha$ yaitu 0,05. Dengan demikian Ho ditolak dan Ha diterima, artinya variabel bebas kompetensi kerja (X1) dan semangat kerja (X2) secara bersama-sama berpengaruh terhadap variabel terikat prestasi kerja guru.

\section{Pembahasan}

Dari hasil pengujian di atas, maka akan diuraikan pembahasan sebagai berikut :

1. Pada hasil uji validitas dan reliabilitas diketahui bahwa semua item pertanyaan memiliki valid dan reliabel.

2. Dari hasil regresi berganda diperoleh nilai koefisien yang positif semua, hal ini menunjukkan bahwa setiap kenaikan variabel $\mathrm{X}$ akan diikuti dengan variabel $\mathrm{Y}$.

3. Pada hasil uji asumsi klasik diperoleh bahwa persamaan regresi sudah memenuhi asumsi klasik yaitu datanya normal dan tidak terjadi autokorelasi, tidak terjadi heteroskedastisitas.

4. Bahwa nilai koefisien korelasi (R) adalah positif. Artinya hubungan antara varaibel bebas yaitu variabel kompetensi kerja (X1) dan semangat kerja (X2) terhadap variabel terikat prestasi kerja guru kuat searah. Dimana perubahan kenaikan yang terjadi ada variabel bebas.

5. Variabel semangat kerja (X2) memiliki koefisien beta yaitu sebesar 0,436 dibanding dengan variabel lain yaitu kompetensi kerja (X1) yaitu sebesar 0,392 dengan demikian semangat kerja (X2) memiliki pengaruh yang dominan dibandingkan variabel bebas kompetensi kerja (X1) terhadap (Y)

6. Pada pengujian dengan uji t diketahui bahwa variabel bebas yaitu kompetensi kerja (X1) dan semangat kerja (X2) berpengaruh baik secara parsial terhadap Prestasi kerja Guru (Y). Analisis data menunjukkan tingkat penerimaan dari syarat yang ditetapkan, yaitu nilai P. SIG yang ada sesuai dengan Tabel COEFFECIENT diperoleh nilai 0,005 untuk variabel bebas kompetensi kerja (X1) dan nilai 0,004 untuk variabel semangat kerja (X2) yang berada di bawah batas 0.05. Dengan demikian dapat dinyatakan bahwa hipotesis kedua terbukti kebenarannya.

7. Pada pengujian dengan uji $\mathrm{F}$ diketahui bahwa variabel bebas yaitu kompetensi kerja (X1) dan semangat kerja (X2) berpengaruh baik secara simultan terhadap prestasi kerja guru. Analisis data menunjukkan tingkat penerimaan dari syarat yang ditetapkan, yaitu nilai P. SIG yang ada sesuai dengan Tabel (ANOVA) sebesar 0.012 yang berada di bawah batas 0.05. Dengan demikian dapat dinyatakan bahwa hipotesis pertama terbukti kebenarannya

Penilaian prestasi kerja merupakan puncak proses managerial. Bagi seorang pimpinan, penilaian prestasi ini merupakan salah satu bagian tugas penting untuk dilakukan secara benar. Seseorang dikatakan berprestasi baik, apabila hasil yang telah diperoleh mencapai standar yang telah ditentukan. Untuk mencapai standar yang telah ditentukan dan prestasi kerja yang lebih tinggi, maka dibutuhkan adanya motivasi untuk melaksanakan pekerjaan. Prestasi kerja yang tinggi dari guru memberi dorongan pada pengembangan kompetensi kerja sehingga pada setiap diri guru memiliki peranan penting untuk memberikan kontribusi pada kinerja guru. Prestasi kerja yang tinggi dari guru ditandai dengan berkembangnya kompetensi kerja. Kompetensi kerja adalah suatu kapasitas individu secara menyeluruh untuk mengerjakan berbagai pekerjaannya. Kompetensi diperlukan seseorang untuk menyelesaikan pekerjaan. Hal ini berarti bahwa untuk menyelesaikan suatu pekerjaan selalu masih tersedia suatu tingkat kemampuan yang belum 
dipergunakan oleh seseorang. Kompetensi menunjukkan potensi dan kemampuan orang untuk melaksanakan tugas atau pekerjaannya. Kompetensi berhubungan erat dengan kemauan, pengetahuan, kemampuan fisik dan mental yang dimiliki oleh seseorang untuk melaksanakan pekerjaannya. Setiap jenis pekerjaan menuntut pengetahuan, keterampilan dan sikap tertentu agar dapat melaksanakan pekerjaan tersebut dengan baik. Untuk mencapai prestasi setinggi-tingginya seseorang harus mengeluarkan seluruh kemampuannya secara optimal.

Selain diadakan pengembangan diperlukan juga upaya peningkatan semangat kerja untuk menggairahkan suasana kerja. Para atasan harus secara bijak memperhatikan kebutuhan para guru secara tepat. Semangat kerja guru juga dapat menurun apabila pihak atasan tidak memperhatikan kepentingan para bawahan. Hal ini akan menurunkan semangat kerja para guru. Indikator dari turunnya semangat kerja antara lain rendahnya produktivitas, tingkat absensi guru tinggi, gaji rendah, dan lain-lain. Dengan demikian pastilah akan mempengaruhi semangat kerja guru di suatu organisasi. Kebutuhan terpenuhi dalam waktu relatif lama tidak dapat menjadi motivator yang aktif selama ini dilakukan. Ia tidak ingin meningkatkan kerja. Kebutuhan yang tidak terpenuhi menyebabkan orang dapat menunjukkan sikap menentang, dan bahkan frustasi, dan jika hal ini terjadi pada guru dapat menyebabkan kurangnya gairah kerja untuk melakukan tugasnya. Orang bekerja keras bila mereka merasa bahwa kerja kerasnya akan mendapat penghargaan yang bernilai bagi organisasinya. Manusia memiliki semangat kerja yang bersifat positif maupun negatif serta motivasi berupa material atau sosial/kejiwaan. Melalui semangat kerja akan diharapan hasilnya lebih baik karena disertai kegairahan dan keikhlasan untuk bekerja. Pada akhirnya dengan kompetensi dan semangat yang optimal diharapkan akan membentuk prestasi kerja guru yang optimal pula.

Semangat adalah kesediaan untuk melakukan usaha atau kerja yang lebih optimal untuk menuju ke arah pencapaian tujuan organisasi dan pemenuhan kebutuhan individu. Kemampuan dapat muncul dari kepemimpinan yang dapat diterima oleh anggota organisasi. Dengan kepemimpinan yang tepat maka organisasi dapat berharap banyak kepada prestasi kerja anggota-anggotanya. Dengan meningkatnya semangat kerja, maka pekerjaan akan lebih cepat diselesaikan dan semua pengaruh buruk dari menurunnya semangat kerja seperti absensi dan selanjutnya akan dapat diperkecil dan selanjutnya menaikkan semangat dan gairah kerja yang berarti diharapkan juga meningkatkan produktivitas guru.

\section{PENUTUP}

\section{Simpulan}

Penelitian ini menyimpulkan beberapa hal sebagai berikut:

1. Kompetensi kerja dan semangat kerja terbukti memiliki pengaruh nyata secara parsial terhadap prestasi kerja guru

2. Kompetensi kerja dan semangat kerja terbukti memiliki pengaruh nyata secara simultan terhadap prestasi kerja guru

3. Semangat kerja terbukti berpengaruh dominan secara signifikan dibandingkan kompetensi kerja terhadap prestasi kerja guru. 


\section{Saran-saran}

Hal-hal yang dapat dijadikan pertimbangan dan masukan dari hasil studi ini adalah sebagai berikut:

1. Keadaan di tempat yang dirasakan oleh setiap guru secara psikologis akan mampu memberikan semangat bagi mereka untuk melakukan pekerjaannya secara bersungguh-sungguh dan mengembangkan potensi diri mereka, sehingga mereka memiliki kepercayaan diri dan selanjutnya memberi pengaruh secara langsung kepada prestasi kerja yang diharapkan akan lebih meningkat menjadi lebih baik

2. Untuk mengembangkan kualitas sumber daya manusia, selain semangat kerja juga diperlukan diadakannya program pelatihan terhadap guru. Hal ini diharapkan akan meningkatkan efektivitas dan efisiensi kerja, juga untuk mempercepat pemantapan perwujudan perilaku yang diinginkan organisasi terhadap guru. Upaya ini sangat penting karena untuk mendukung tugastugas yang dibebankan kepada guru sehingga hasil dari upaya-upaya tersebut akan mendukung pencapaian tujuan organisasi

3. Prestasi kerja yang tinggi dari guru memberi dorongan pada pengembangan selanjutnya kemampuan dan keterampilan sehingga pada setiap diri guru memiliki peranan penting untuk memberikan kontribusi pada prestasi kerja guru. Prestasi kerja yang tinggi dari guru ditandai dengan meningkatnya semangat dan gairah kerja. Dengan demikian, pekerjaan akan lebih cepat diselesaikan dan semua pengaruh buruk yang muncul akan segera diatasi dengan cepat.

\section{DAFTAR PUSTAKA}

Adnyani, I.G. 2008. Membina Semangat Kerja untuk Meningkatkan Produktivitas Kerja Karyawan. Buletin Studi Ekonomi Vol. 13, No. 2

Ariyanto, Dodik. 2009. Pengaruh Independensi, Kompetensi, Dan Sensitivitas Etika Profesi Terhadap Produktivitas Kerja Auditor Eksternal (Studi Kasus Pada Auditor Perwakilan BPK RI Provinsi Bali). Skripsi. Jurusan Akuntansi Fakultas Ekonomi. Bali : Universitas Udayana.

Darmawan, Didit. 2013. Prinsip-Prinsip Perilaku Organisasi. Pena Semesta, Surabaya.

Dharma, Surya. 2005. Manajemen Kinerja. Jakarta : Pustaka Pelajar.

Gujarati, Damondar. 2006. Ekonometrika Dasar. Jakarta: Erlangga.

Hasibuan, Melayu S.P. 2005. Manajemen Sumber Daya Manusia. Edisi Revisi. Cetakan Keenam. Jakarta: Penerbit Bumi Aksara.

Istijanto. 2008. Riset Sumber Daya Manusia. Jakarta: PT Gramedia Pustaka Utama.

Kreitner, Robert dan Angelo Kinicki. 2003. Perilaku Organisasi. Edisi Pertama. Jakarta: Salemba Empat.

Mangkunegara, Prabu Anwar. 2002. Manajemen Sumber Daya Organisasi. Bandung : PT Remaja Rosdakarya.

Mathis, Robert L, dan Jackson, John H, 2002, Manajemen Sumber Daya Manusia. Jakarta : Salemba Empat. 
Moekijat. 2003. Manajemen Kepegawaian. Jakarta : Penerbit PT. Bumi Aksara.

Nitisemito, Alex S. 2000. Manajemen Personalia: Manajemen Sumber Daya Manusia. Ed. 3. Jakarta : Ghalia Indonesia.

Pfeffer .J, Soetjipto Budi W, Handoko T. Hani, dkk, 2003, Paradigma Baru Manajemen Sumber Daya Manusia, Editor A. Usmara, Cetakan Keempat, Edisi Kedua. Yogyakarta : Penerbit Amara Books.

Ruky, Ahmad S. 2003. Manajemen Kinerja. Jakarta : Bumi Aksara.

Sastrohadiwiryo, Siswanto. 2002. Manajemen Tenaga Kerja Indonesia. Jakarta : Bumi Aksara

Siagian, S. 2002. Manajemen Sumber Daya Manusia. Jakarta: PT Bumi Aksara.

Siswanto-Sastrohadiwiryo, B. 2002. Manajemen Tenaga Kerja Indonesia: Pendekatan Administratif dan Operasional. Jakarta : Bumi Aksara.

Sumarsono, Sony. 2004. Metode Riset Sumber Daya Manusia. Yogyakarta: Graha Ilmu.

Suyadi, Prawirosentono. 1999. Manajemen Sumber Daya Manusia. "Kebijakan Kinerja Karyawan. Yogyakarta : Penerbit BPFE.

Thoha, Miftah. 2001. Perilaku Organisasi Konsep Dasar dan Aplikasinya. Jakarta: PT RajaGrafindo Persada.

Triastuti, Leny. 2009. Pengaruh Motivasi Kerja Dan Kompetensi Kerja Terhadap Prestasi Kerja Karyawan Kantor Pelayanan Dan Pengawasan Bea\&Cukai Tipe A3 Surakarta. Skripsi. Surakarta : Universitas Muhammadiyah.

Zaelani, Rizal. 2010. Pengaruh Pemberdayaan dan Kompetensi Terhadap Kinerja Karyawan (Suatu Studi Pada Karyawan RSUD Sekarwangi Kabupaten Sukabumi). Skripsi. Jakarta : Universitas Suryadarma.

Zainun, Buchari. 2001. Manajemen Sumber Daya Manusia Indonesia. Jakarta : PT Gunung Agung. 